Arq. Bras. Med. Vet. Zootec., v.67, n.5, p.1217-1225, 2015

\title{
Prevalência das infecções latentes por BoHV-1 e BoHV-5 em bovinos de corte no Estado do Paraná
}

\author{
[Prevalence of latent infection with BoHV-1 and BoHV-5 in beef cattle of Parana, Brazil] \\ R.A.M. Oliveira, E. Lorenzetti, A.A. Alfieri, J.A.N. Lisbôa ${ }^{*}$ \\ Universidade Estadual de Londrina - UEL - Londrina, PR
}

\begin{abstract}
RESUMO
O objetivo deste trabalho foi determinar a prevalência das infecções latentes por BoHV-1 e por BoHV-5 em bovinos de corte criados no Estado do Paraná. Os gânglios do nervo trigêmeo foram coletados de 400 bovinos hígidos, entre 18 e 36 meses de idade, provenientes de 90 propriedades rurais localizadas em diferentes mesorregiões geográficas do Estado e abatidos em frigorífico com Serviço de Inspeção Federal. A reação em cadeia da polimerase com amplificação do gene que codifica a glicoproteína $\mathrm{C}$ foi empregada para a detecção do DNA viral. Cento e nove bovinos eram herpéticos $(27,25 \%)$, sendo 14,25\% (57/400) infectados com BoHV-1, 9,75\% (39/400) infectados com BoHV-5 e 3,25\% (13/400) portadores de infecção mista. A distribuição geográfica foi heterogênea e as infecções foram mais prevalentes nas mesorregiões localizadas ao norte do Estado. A vigilância para a encefalite por BoHV-5 deve ser intensificada na mesorregião Noroeste.
\end{abstract}

Palavras-chave: herpes-vírus bovino, diagnóstico, epidemiologia, doenças neurológicas

\begin{abstract}
The prevalence of latent infection with BoHV-1 or BoHV-5 in beef cattle raised in the state of Paraná, Brazil, was studied. The trigeminal ganglia were collected in a slaughterhouse from 400 healthy cattle, 18 to 36 months old, raised in 90 farms located in distinct geographical regions of the state. Polymerase chain reaction for amplification of the gene encoding $C$ glycoprotein was performed to detect virus DNA. One hundred and nine (27.25\%) animals were herpetic; $14.25 \%$ (57/400) were infected with BoHV-1, 9.75\% (39/400) were infected with BoHV-5 and 3.25\% (13/400) had mixed infection. The geographical distribution was heterogeneous and the infections were more prevalent in the north of the state. The surveillance for BoHV-5 encephalitis should be intensive in the Northwest region.
\end{abstract}

Keywords: bovine herpesvirus, diagnosis, epidemiology, neurological diseases

\section{INTRODUÇÃO}

O BoHV-5 é o agente etiológico da meningoencefalite herpética dos bovinos, doença que acomete principalmente animais jovens, com até 24 meses de idade (Colodel et al., 2002; Claus et al., 2007), e se caracteriza por apresentar índices de morbidade baixos e taxa de letalidade elevada (Lisbôa et al., 2009). A encefalite por BoHV-5 é relatada com maior frequência em países da América do Sul, com destaque para o Brasil, onde é considerada,

Recebido em 24 de março de 2014

Aceito em 27 de fevereiro de 2015

*Autor para correspondência (corresponding author)

E-mail: janlisboa@uel.br depois da raiva, a principal causa de encefalite em bovinos (Rissi et al., 2010; Queiroz et al., 2013).

O BoHV-1 apresenta distribuição mundial e está associado a uma variedade de enfermidades, tais como doença respiratória (Rinotraqueíte Infecciosa Bovina - IBR), doença sistêmica em bezerros neonatos, doenças reprodutivas (Vulvovaginite e Balanopostite Infecciosa Bovina - IPV e IBP) e abortamentos (Nandi et al., 2009; Henzel et al., 2008). Eventualmente, a infecção pode provocar encefalite (Rissi et al., 2008). 
Uma característica comum a ambos os vírus é a capacidade de determinar infecção latente duradoura em seus hospedeiros, possibilitando a excreção ocasional do agente para o ambiente, após eventos que favorecem a reativação viral (Meyer et al., 2001; Vogel et al., 2003). Os gânglios dos nervos sensoriais que inervam os sítios primários de infecção são os tecidos de eleição para o estabelecimento da latência, e tanto BoHV-1 quanto BoHV-5 permanecem em latência nos gânglios do nervo trigêmeo após a infecção por via respiratória (Meyer et al., 2001; Vogel et al., 2003).

No Estado do Paraná, a infecção por herpes-vírus bovino tem sido identificada, em rebanhos, por levantamentos soroepidemiológicos (Médici et al., 2000; Takiuchi et al., 2001; Dias et al., 2013), e a presença de BoHV-5 foi confirmada nos casos de encefalite em bovinos (Claus et al., 2007; Lisbôa et al., 2009; Lunardi et al., 2009). Devido à grande similaridade genômica dos dois vírus, ocorre intensa reatividade cruzada, impossibilitando que as infecções específicas por BoHV-1 e por BoHV-5 sejam diferenciadas por métodos sorológicos (Holz et al., 2009). Dessa forma, a prevalência específica de cada um dos herpes-vírus bovino é desconhecida no Estado. O objetivo deste trabalho foi determinar a prevalência de infecções latentes por BoHV-1 ou por BoHV-5 em bovinos de corte criados nas diferentes mesorregiões do Estado do Paraná, utilizando a técnica da reação em cadeia da polimerase (PCR) para a detecção do DNA viral nos gânglios do nervo trigêmeo.

\section{MATERIAL E MÉTODOS}

O projeto foi aprovado pela Comissão de Ética no Uso de Animais da Universidade Estadual de Londrina (CEUA/UEL) sob o número de processo 31235.2011 .

Entre os meses de março e junho de 2012, gânglios do nervo trigêmeo (direito e esquerdo) foram colhidos de 400 bovinos de corte sadios, abatidos no Matadouro-Frigorífico Argus Ltda., com registro no Serviço de Inspeção Federal (SIF) do Ministério da Agricultura, Pecuária e Abastecimento (MAPA) e localizado no município de São José dos Pinhais, Paraná. Os animais eram da raça Nelore ou seus cruzamentos, machos e fêmeas, entre 18 e 36 meses de idade, e manejados extensivamente em propriedades rurais paranaenses.

Para o cálculo do número de amostras, foi considerada a prevalência esperada de $50 \%$ para as infecções por BoHV-1 e por BoHV-5, com erro de $6 \%$ e nível de significância de $5 \%$. A fórmula para amostras simples aleatórias (Thursfiel, 1995) foi aplicada com auxílio do programa Epi Info, versão 6.04: $\mathrm{n}=Z_{\alpha}{ }^{2} \cdot \sqrt{ } P(1-$ $P) / d^{2}$

em que: $\mathrm{n}=$ número de amostras necessárias; $\mathrm{Z} \alpha=$ valor de distribuição normal para o grau de confiança de $95 \%$; $P=$ prevalência esperada; $d=$ precisão (fixada em $6 \%$ ).

Para a amostragem da população bovina distribuída geograficamente pelo Estado do Paraná, foi adotado o modelo de divisão em 10 mesorregiões, segundo o Instituto Brasileiro de Geografia e Estatística (IBGE) (Tab. 1). A partir do efetivo total de bovinos existente em cada mesorregião (Produção..., 2010), calculou-se o número de bovinos de corte subtraindo-se do total estimado de bovinos leiteiros. A população de bovinos leiteiros foi estimada a partir da informação do total de vacas em lactação presente em cada mesorregião (Paraná, 2010), considerando-se que essa categoria corresponde a $70 \%$ do total de bovinos em uma propriedade leiteira. $\mathrm{O}$ número de amostras definido para a colheita obedeceu à mesma proporção do efetivo de bovinos de corte existente entre as mesorregiões geográficas paranaenses (Tab. 1).

Os bovinos foram selecionados aleatoriamente na linha de abate, tomando-se como critérios a homogeneidade da idade, determinada por inspeção dos dentes, e a heterogeneidade da origem, considerando o município e a propriedade. Para garantir a maior abrangência geográfica possível, os animais foram provenientes de 48 municípios e eram criados em 90 propriedades rurais distintas. Foram colhidas amostras de um a, no máximo, oito bovinos de um mesmo rebanho. 
Tabela 1. Distribuição da população de bovinos de corte e leiteiros nas diferentes mesorregiões do Estado do Paraná e o número de amostras colhidas por mesorregião

\begin{tabular}{lccccc}
$\begin{array}{l}\text { Mesorregião } \\
\text { Geográfica }\end{array}$ & $\begin{array}{c}\text { Bovinos } \\
\text { em geral }\end{array}$ & $\begin{array}{c}\text { Bovinos } \\
\text { leiteiros }^{\mathrm{b}}\end{array}$ & $\begin{array}{c}\text { Bovinos } \\
\text { de corte }\end{array}$ & $\begin{array}{c}\text { Número de } \\
\text { amostras }\end{array}$ \\
& $(n)$ & $(n)$ & $(n)$ & $(\%)$ & \\
Centro Ocidental & 583.015 & 105.881 & 477.134 & 6,56 & 27 \\
Centro Oriental & 661.668 & 142.244 & 519.424 & 7,14 & 29 \\
Centro Sul & 1.062 .187 & 288.964 & 773.223 & 10,63 & 42 \\
Curitiba & 228.773 & 80.441 & 148.332 & 2,04 & 8 \\
Noroeste & 2.168 .501 & 281.309 & 1.887 .192 & 25,95 & 104 \\
Norte Central & 1.359 .649 & 266.403 & 1.093 .246 & 15,03 & 60 \\
Norte Pioneiro & 1.008 .096 & 187.516 & 820.580 & 11,28 & 45 \\
Oeste & 1.187 .351 & 458.580 & 728.771 & 10,02 & 40 \\
Sudeste & 256.093 & 72.216 & 183.877 & 2,52 & 10 \\
Sudoeste & 1.046 .78 & 407.581 & 639.199 & 8,79 & 35 \\
& & & & & 400 \\
Total & 9.562 .113 & 2.291 .135 & 7.270 .978 & 100 & 400 \\
\hline
\end{tabular}

${ }^{a}$ Produção da Pecuária Municipal (Brasil, 2010).

bPopulação estimada a partir do número total de vacas leiteiras em lactação (Paraná, 2010).

Os gânglios do nervo trigêmeo (direito e esquerdo) foram dissecados após a abertura do crânio e a remoção do encéfalo, sendo acondicionados em sacos plásticos identificados, transportados sob refrigeração e mantidos a $80^{\circ} \mathrm{C}$ até $\mathrm{o}$ processamento. Para evitar a transferência acidental de DNA viral entre as amostras, empregou-se material cirúrgico desinfetado com solução de hipoclorito de sódio $10 \%$ (concentração de $1.000 \mathrm{ppm}$ de cloro ativo) e trocou-se a lâmina do bisturi a cada animal.

As amostras foram processadas em cabine de segurança e a sequência das amostras nos lotes de processamento foi aleatória para evitar que indivíduos de uma mesma mesorregião fossem analisados em conjunto ou muito próximos. Os gânglios do nervo trigêmeo (direito e esquerdo) de cada bovino foram processados em conjunto, gerando amostra única por indivíduo. Para a extração do ácido nucleico, utilizou-se a combinação dos métodos fenol/clorofórmio/álcool isoamílico e sílica/isotiocianato de guanidina (Alfieri et al., 2006).

O DNA extraído foi submetido à PCR com modificações realizadas no método descrito por Claus et al. (2005), utilizando-se primers baseados no gene que codifica a glicoproteína $\mathrm{C}$ do envelope viral. Para a detecção de BoHV-1, realizou-se a primeira PCR empregando-se o par de primers $\mathrm{B} 1$, específico para BoHV-1 ([5'CAA CCG AGA CGG AAA GCT CC- 3'], nt 185-204), e Bcon, primer consensual para BoHV-1 e para BoHV-5 ([5'-AGT GCA CGT ACA GCG GCT CG-3'], nt 519-538 [BoHV-1] e nt 461-480 [BoHV-5]). A segunda PCR foi realizada para a detecção de BoHV-5, utilizandose, novamente, o primer consensual Bcon em associação com o primer $\mathrm{B} 5$, específico para BoHV-5 ([5'-CGG ACG AGA CGC CCT TGG3'], nt 322-339). Fragmentos com 354 pares de base (pb) e $159 \mathrm{pb}$ foram amplificados para BoHV-1 e para BoHV-5, respectivamente.

A PCR foi realizada separadamente para cada vírus, utilizando-se $5 \mu \mathrm{L}$ do ácido nucleico extraído e $45 \mu \mathrm{L}$ de mix, constituído por 0,4 pmol de cada primer (B1 e Bcon) ou (B5 e Bcon); $2 \mathrm{mM}$ de dNTP (Invitrogen ${ }^{\mathrm{TM}}$ Life Technologies, EUA); 5 Unidades de Platinum Taq DNA polymerase (Invitrogen ${ }^{\mathrm{TM}}$ Life Technologies, São Paulo, Brasil); 1x PCR buffer (50mM KCl e $20 \mathrm{mM}$ Tris- $\mathrm{HCl} \mathrm{pH} 8,4) ; 1,5 \mathrm{mM} \mathrm{MgCl}{ }_{2} ; 8 \%$ de dimetilsulfóxido (DMSO, Sigma Co., EUA) e água ultrapura estéril para o volume final de $50 \mu \mathrm{L}$. A amplificação foi realizada em termociclador (PTC 200, MJ Research Co., EUA), sob as seguintes condições de tempo e temperatura: $94^{\circ} \mathrm{C} / 3 \mathrm{~min}$, seguido de 35 ciclos a $94^{\circ} \mathrm{C} / 1 \mathrm{~min}, \quad 58^{\circ} \mathrm{C} / 30 \mathrm{~s}, \quad 72^{\circ} \mathrm{C} / 1 \mathrm{~min}$ e extensão final a $72^{\circ} \mathrm{C} / 7 \mathrm{~min}$. 
Os produtos da PCR foram analisados por eletroforese em gel de agarose $2 \%$, em tampão TBE com $\mathrm{pH}$ 8,4 (89mM Tris; $89 \mathrm{mM}$ ácido bórico e $2 \mathrm{mM}$ EDTA) e sob voltagem constante $(100 \mathrm{~V})$ por aproximadamente $45 \mathrm{~min}$, corados com brometo de etídeo $(0,5 \mu \mathrm{g} / \mathrm{mL})$ e visualizados sob luz ultravioleta.

Controles positivo e negativo foram utilizados a cada nove amostras. Os protótipos utilizados como controle positivo foram: cepa Los Angeles para BoHV-1 e cepa AA 01 para BoHV-5 (D'Arce et al., 2002). PBS foi empregada como controle negativo. A qualidade do procedimento de extração foi avaliada por um controle interno da reação, baseado no gene ND5 do DNA mitocondrial bovino (Claus et al., 2005), gerando um fragmento com $626 \mathrm{pb}$. A cada 50 amostras com resultado negativo, nove foram escolhidas, de forma aleatória, e processadas com o controle da reação.

Produtos da PCR para BoHV-1 $(n=2)$ e para BoHV-5 $(n=1)$ foram submetidos ao sequenciamento. Os produtos foram purificados utilizando-se o Kit Ilustra GFX'TM PCR DNA e Gel Band Purification (GE Healthcare, Little Chalfont, UK), quantificados utilizando-se o Kit Qubit $^{\mathrm{TM}}$ Fluorometer (Invitrogen ${ }^{\mathrm{TM}}$ Life Technologies, EUA) e sequenciados no ABI3500 Genetic Analyzer com o Kit BigDye ${ }^{\circledR}$ Terminator v.3.1 Cycle Sequencing (Applied Biosystems ${ }^{\circledR}$, EUA), usando-se primers senso e anti-senso.

As sequências obtidas foram analisadas utilizando-se os programas Phred e CAP3 (http://asparagin.cenargen.embrapa.br/phph/) e somente bases com qualidade maior ou igual a 20 foram consideradas. As sequências foram analisadas no programa Basic Local Alignment Search Tool (BLAST http://blast.ncbi.nlm.nih.gov/Blast.cgi) para verificar a similaridade de nucleotídeos com sequências depositadas em bases públicas de dados (GenBank). O alinhamento foi realizado no CLUSTAL W, com auxílio do programa MEGA (versão 4.1), e a matriz identidade foi realizada no Bio Edit (versão 7.0.9.0).

Foram estabelecidas as distribuições de frequência das infecções latentes, simples (por cada herpes-vírus individualmente) e mistas, globais e em cada mesorregião geográfica do Estado do Paraná. O teste de Qui-quadrado foi empregado para verificar diferenças entre as proporções dos tipos de infecção latente (simples e mista) e entre as prevalências nas mesorregiões geográficas.

\section{RESULTADOS}

A infecção latente por herpes-vírus foi confirmada em 109 dos 400 bovinos estudados (Tab. 2). Considerando somente os bovinos infectados, 52,3\% (57/109) albergavam exclusivamente BoHV-1, 35,8\% (39/109) estavam infectados especificamente por BoHV-5 e $11,9 \%(13 / 109)$ eram portadores de ambos os vírus. As infecções simples, por BoHV-1 ou por BoHV-5, apresentaram prevalências que não diferiram entre si $(\mathrm{P}>0,05)$, e foram mais frequentes do que a infecção mista $(\mathrm{P}<0,001)$.

As infeções latentes por herpes-vírus foram confirmadas em 47,8\% (43/90) dos rebanhos amostrados. Em 17 rebanhos (18,9\%), havia infecção somente com BoHV-1, e em oito rebanhos $(8,9 \%)$, somente com BoHV-5. A presença simultânea de ambos os vírus circulando no mesmo rebanho foi confirmada em 18 propriedades $(20 \%)$, sendo a infeção mista observada em oito $(8,9 \%)$, enquanto as infecções simples em animais diferentes ocorreram nas demais $10(11,1 \%)$.

Tabela 2. Prevalência das infecções latentes, simples e mistas, por BoHV-1 e BoHV-5, confirmadas nos gânglios do nervo trigêmeo de bovinos de corte sadios $(n=400)$, criados e abatidos no Estado do Paraná

\begin{tabular}{lccc} 
Tipo de infecção & $n$ & $\%$ & IC da prevalência \\
\hline & 57 & 14,25 & \\
BoHV-1 & 39 & 9,75 & 9,47 a 19,02 \\
BoHV-5 & 13 & 3,25 & 0,22 a 17,30 \\
BoHV1 + BoHV-5 & & & 0 a 8,37 \\
Total & 109 & 27,25 & 18,62 a 35,87 \\
\hline
\end{tabular}


As infecções por BoHV-1 ou por BoHV-5 não se apresentaram com distribuição geográfica uniforme no Estado do Paraná (Fig. 1), e as prevalências variaram entre as mesorregiões $(\mathrm{P}<0,001)$. A infecção latente por BoHV-1 foi observada em sete das dez mesorregiões geográficas, com exceção das de Curitiba, Sudeste e Centro Sul. Essas mesorregiões apresentam localização mais ao sul do Estado e são contíguas entre si. O número de amostras colhidas nas mesorregiões de Curitiba $(n=8)$ e Sudeste $(n=10)$ foi reduzido porque a população de bovinos de corte não é numerosa (Fig. 1). O mesmo não pode ser afirmado na mesorregião Centro Sul, que originou $10,5 \%$ de todas as amostras colhidas para o estudo. Nas mesorregiões em que a infecção foi comprovada, a prevalência variou consideravelmente, de $6,9 \%$ até $36,6 \%$.

Em comparação à infecção por BoHV-1, a por BoHV-5 distribuiu-se de forma menos uniforme pelo Estado e foi confirmada em somente metade das mesorregiões, concentrando-se naquelas localizadas ao norte. Dentre as que constituem a fronteira sul, apresentou-se apenas na mesorregião Sudoeste. As prevalências variaram com valores reduzidos $(2,2 \%$ a $5,7 \%)$, exceto nas mesorregiões Norte Central e Noroeste.

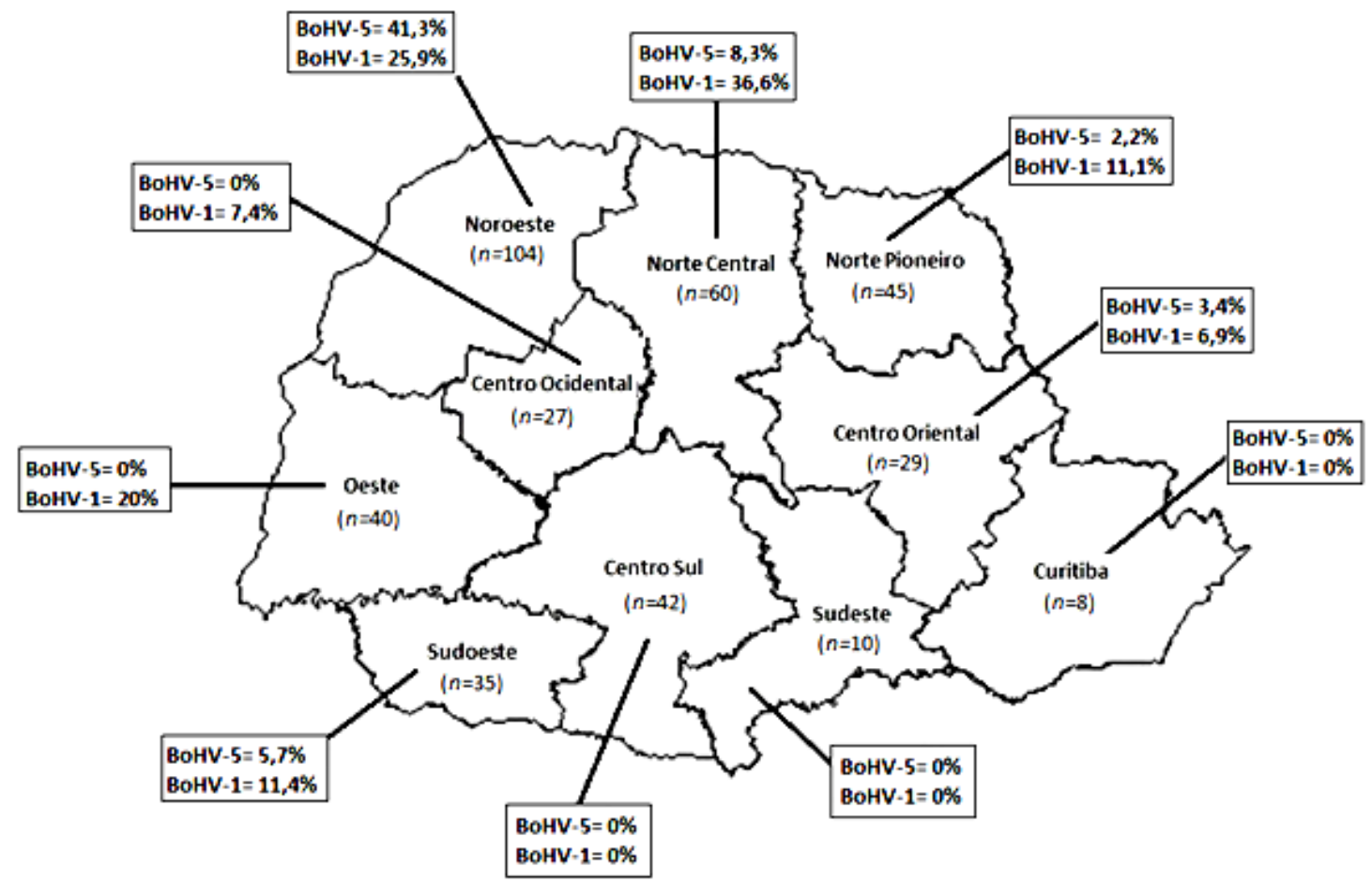

Figura 1. Prevalência dos herpes-vírus bovinos 1 (BoHV-1) e 5 (BoHV-5) nas diferentes mesorregiões do Estado do Paraná. Mapa adaptado de IBGE (www.ibge.gov.br).

Os resultados da matriz de identidade de nucleotídeos comprovaram a presença de BoHV1 ou de BoHV-5 nas três amostras selecionadas para o procedimento. Com relação a BoHV-1, as amostras UEL 7 e UEL 323 apresentaram, respectivamente, $99,7 \%$ e $99,4 \%$ de identidade de nucleotídeos com as sequências NM06 (número de acesso JN787953) e SV-56/90 (número de acesso EF613331). As amostras avaliadas apresentaram, entre si, 99,7\% de identidade de nucleotídeos. Quanto a BoHV-5, a amostra UEL 237 apresentou 99,3\% de identidade de nucleotídeos com as sequências EVI-190 (número de acesso AY052396) e TX89 (número de acesso U35883), e com a sequência que pertence ao número de acesso Z49224. 


\section{DISCUSSÃO}

A infecção por herpes-vírus bovino em rebanhos brasileiros vem sendo comprovada, nas últimas três décadas, por meio de levantamentos soroepidemiológicos, os quais empregaram, na maior parte das vezes, a técnica de virusneutralização. Levantamentos realizados no Rio Grande do Sul (Holz et al., 2009), São Paulo (Richtzenhain et al., 1999) e Mato Grosso do Sul (Richtzenhain et al., 1999; Takiuchi et al., 2001) apontaram prevalência sempre maior do que 29\%. No Estado do Paraná, prevalências de 43,7\% (Médici et al., 2000), 52,4\% (Takiuchi et al., 2001) e 59\% (Dias et al., 2013) vêm sendo comprovadas.

Apesar de ser inquestionável a importância desses levantamentos como indicadores da presença e da distribuição da infecção por herpes-vírus na população bovina, eles apresentam, como limitação, a impossibilidade de determinar a espécie viral que está ocasionando a infecção. Em todos esses estudos admitiu-se que se tratava da infecção por BoHV1. Entretanto, não é possível saber quantos animais positivos eram, de fato, infectados por BoHV-5 em vez de BoHV-1. Os dois vírus apresentam semelhanças genômicas e antigênicas, o que determina que a reação cruzada seja intensa entre ambos e que os métodos sorológicos clássicos sejam incapazes, portanto, de detectar anticorpos específicos para cada vírus (Holz et al., 2009).

Casos naturais de encefalite em bovinos causada por BoHV-5 já foram confirmados em diferentes Estados brasileiros: Rio Grande do Sul (Elias et al., 2004; Rissi et al., 2008; 2010), Mato Grosso do Sul (Salvador et al., 1998), São Paulo (Salvador et al., 1998; Gomes et al., 2002; Lisbôa et al., 2009), Minas Gerais (Gomes et al., 2002) e Mato Grosso (Colodel et al., 2002). No Paraná, a doença também ocorre (Claus et al., 2007; Lisbôa et al., 2009; Lunardi et al., 2009) e deve ser considerada, depois da raiva, a principal causa de encefalite em bovinos (Queiroz et al., 2013). Apesar de reconhecida como importante, em virtude dos relatos de doença, a infecção por BoHV-5 na população bovina nunca havia sido determinada até o estudo de Campos et al. (2009). Realizado no Rio Grande do Sul, o trabalho consistiu na detecção da presença dos genomas de BoHV-5 e de BoHV-1 nos gânglios do nervo trigêmeo de bovinos de corte sadios criados e abatidos no sul do Estado. A infecção latente com herpes-vírus bovino foi confirmada em $87 \%$ dos bovinos amostrados. Dentre estes, $6,9 \%$ eram infectados exclusivamente com BoHV-1, 17,2\% exclusivamente com BoHV-5 e $75,9 \%$ estavam infectados com ambos os vírus

$\mathrm{O}$ estudo aqui apresentado é o segundo levantamento realizado no Brasil com determinação das prevalências das infecções específicas por cada um dos herpes-vírus, e o primeiro realizado no Paraná. Distintamente do estudo de Campos et al. (2009), envolveu o dobro do número de bovinos e investigou a distribuição das infecções latentes nas diferentes mesorregiões geográficas do Estado. Os resultados obtidos nos dois Estados são distintos, sendo as prevalências observadas no Rio Grande do Sul muito mais altas do que as do Paraná. São diferentes, sobretudo, com relação à taxa de infecção mista.

As discrepâncias entre os resultados obtidos nos dois estudos podem ser devidas a algumas diferenças metodológicas. Ao contrário do protocolo adotado no presente trabalho, Campos et al. (2009) realizaram duas PCR seguidas, o que pode acarretar diferenças de sensibilidade e de especificidade entre os métodos utilizados para a identificação da presença do genoma viral. Os bovinos do Paraná eram, pelo menos, um ano mais jovens, e isso poderia significar que tiveram menor chance de se infectar ao longo da vida. Embora nas duas situações os animais fossem mantidos em manejo extensivo, todos os bovinos paranaenses eram Nelore ou seus cruzamentos, e isso difere do padrão racial criado no Rio Grande do Sul, onde predominam as raças europeias. É desconhecido que taurinos sejam mais susceptíveis do que os zebuínos a se infectarem com o herpes-vírus bovino, e não há evidências que sustentem essa hipótese. Conforme demonstrado em estudos de soroprevalência realizados no Paraná, a frequência de sororreagentes pode, até mesmo, ser maior nos rebanhos de corte do que nos de leite (Médici et al., 2000; Dias et al., 2013). A ocorrência da meningoencefalite herpética comumente envolve bovinos de corte, afetando tanto taurinos (Elias et al., 2004; Lunardi et al., 2009) quanto zebuínos (Salvador et al., 1998; Colodel et al., 2002; Lisbôa et al., 2009), sem distinção aparente. 
Os gânglios do nervo trigêmeo foram o tecido selecionado para a avaliação das infecções latentes. Os gânglios sensoriais de nervos que inervam a região onde ocorreu a infecção primária são o sítio de latência desses vírus no organismo do hospedeiro, e, após a infecção por via respiratória, os dois vírus estabelecem latência nos gânglios do nervo trigêmeo (Meyer et al., 2001; Vogel et al., 2003). No caso de BoHV-1, após a infecção genital, os gânglios sacrais (pudendo, genitofemoral, retocaudal e obturador) seriam os tecidos de eleição para a latência (Henzel et al., 2008). Isso poderia ser apontado como causa possível de falha na detecção da presença de BoHV-1 no presente trabalho. Contudo, deve ser destacado que os animais estudados foram criados com a finalidade de abate, e foram abatidos jovens, antes de entrarem em atividade reprodutiva. A via de infecção genital é, portanto, pouco provável nessas condições.

Quanto à distribuição geográfica, é relevante a prevalência alta observada nas três mesorregiões que constituem a fronteira norte do Paraná (Noroeste, Norte Central e Norte Pioneiro). Essas regiões concentram a metade $(52,3 \%)$ da população de bovinos de corte do Estado, caracterizando-se pela presença de propriedades com maior extensão e número elevado de animais (Dias et al., 2013). A situação mostrouse particularmente crítica na mesorregião Noroeste, tradicionalmente reconhecida pela atividade de pecuária de corte. Nessa mesorregião, a maior parte dos rebanhos amostrados apresentou bovinos infectados $(86,9 \%$; 20/23); a prevalência da infecção por BoHV-5 foi muito elevada $(41,3 \%)$ (Fig. 1$)$, e houve a concentração de quase todos os casos de infecções mistas (12/13), observadas em sete dos 23 rebanhos. Se a amostragem do estudo tivesse se restringido às mesorregiões Noroeste e Norte Central, a prevalência de bovinos infectados com herpes-vírus teria sido muito maior $(59,1 \%$; 97/164) do que a observada no Estado por inteiro. Talvez a região sul do Rio Grande do Sul reúna, afinal, caraterísticas particulares que favoreçam a disseminação tão ampla dessas infecções pela população de bovinos residentes, justificando a alta prevalência observada naquele estudo (Campos et al., 2009).

As divisas com São Paulo (as três mesorregiões) e Mato Grosso do Sul (a mesorregião Noroeste) possibilitam a movimentação de animais entre os Estados, favorecendo a disseminação e o compartilhamento dessas infecções. Dados oficiais sobre a movimentação de bovinos no Paraná em 2012, levantados junto à Gerência de Trânsito Agropecuário da Agência de Defesa Agropecuária do Paraná (Adapar), mostram que 97.373 animais deixaram o Estado; 74,7\% deles para São Paulo e 14,5\% para o Mato Grosso do Sul. Pouco mais da metade dos bovinos movimentados $(54,8 \%)$ saiu do Paraná com a finalidade de abate, e, por esse motivo, não contribui para a disseminação das infecções. $\mathrm{O}$ restante, ao contrário, possui importância epidemiológica, pois saiu do Estado para integrar-se a outros rebanhos para engorda $(23,5 \%)$ e reprodução $(20,6 \%)$. No mesmo ano, 53.561 bovinos entraram no Paraná provenientes do Mato Grosso do Sul (54,2\%), de Mato Grosso $(23,8 \%)$ e de São Paulo (9,5\%). A maioria foi incorporada a rebanhos paranaenses para recria e engorda $(80,2 \%)$ ou reprodução $(16,8 \%)$.

No triênio compreendido entre 2009 e 2011, a raiva foi confirmada em $36,8 \%$ dos bovinos paranaenses acometidos por doença neurológica cujo material do encéfalo foi encaminhado para diagnóstico, comprovando-se como a principal causa de encefalopatia nessa espécie (Wesgueber et al., 2012). Ao contrário de outros locais do Estado, a ocorrência da doença foi muito pequena na mesorregião Noroeste $(2,4 \%$ de todos os casos de raiva no período) e isso se deve à reduzida população de morcegos hematófagos presentes na região. Uma vez que a raiva não parece ter importância epidemiológica e que a frequência de infecção com BoHV-5 provou-se tão elevada, é coerente afirmar que a suspeita de encefalite herpética deve ser sempre considerada como uma das primeiras hipóteses na lista de diagnósticos diferenciais para as doenças neurológicas de bovinos criados nessa mesorregião.

É importante mencionar que a distribuição geográfica heterogênea observada neste estudo guarda certa coerência com os resultados obtidos por Dias et al. (2013), em seu levantamento de prevalência de anticorpos séricos contra herpesvírus bovino em vacas paranaenses. Ao contrário do presente trabalho, animais sororreagentes foram identificados em todas as regiões do Estado. Entretanto, os índices de prevalência também foram mais elevados ao norte $(60,2$ a 
$71,1 \%)$ do que ao sul (45,9 a $54,9 \%)$ Considerando somente os rebanhos de corte, 83,9 a $98,5 \%$ dos localizados ao norte, e 58,8 a $93,7 \%$ daqueles localizados ao sul, possuíam animais sororreagentes.

Nas condições em que se desenvolveu este estudo, não foi possível colher amostras de sangue dos bovinos selecionados. A verificação da presença de anticorpos séricos contra herpesvírus bovino em cada indivíduo e a sua correlação com a presença ou não de infecção latente nos gânglios do nervo trigêmeo poderia trazer informação adicional para a interpretação dos resultados. Entretanto, conforme observado por Campos et al. (2009), os resultados dos dois tipos de exames não são obrigatoriamente concordantes. Enquanto a grande maioria dos bovinos $(87 \%)$ era infectada por BoHV-1 e/ou por BoHV-5 na sua forma latente, somente $49,5 \%$ dos animais possuíam títulos de anticorpos neutralizantes. Na região de origem desses bovinos, ao sul do Rio Grande do Sul, a prevalência de fêmeas bovinas sororreagentes também se comprovou relativamente baixa $(28,1 \%$ e $32,5 \%$ nas mesorregiões Sudeste e Sudoeste do Estado, respectivamente) em levantamento contemporâneo (Holz et al., 2009). Isso reforça a discordância entre os resultados e reafirma a dificuldade de interpretação conjunta dos mesmos.

\section{CONCLUSÕES}

Este é o primeiro estudo realizado que determinou a prevalência da infecção latente por BoHV-1 e/ou por BoHV-5 em bovinos no Estado do Paraná. A distribuição nas diferentes mesorregiões geográficas e a identificação do tipo específico de herpes-vírus bovino envolvido foram demonstradas na população de bovinos de corte. Essas informações se somam às descritas anteriormente no Rio Grande do Sul como os dois únicos levantamentos epidemiológicos dessa natureza disponíveis no Brasil. As duas infecções ocorrem em rebanhos paranaenses com distribuição geográfica heterogênea. São mais prevalentes ao norte do Estado, onde se concentra a maior população de bovinos de corte, e estão quase ausentes nas mesorregiões que constituem a fronteira sul. A situação epidemiológica é mais crítica na mesorregião Noroeste, e a vigilância para a meningoencefalite herpética, provocada por BoHV-5, deve ser intensificada na mesma.

\section{AGRADECIMENTOS}

Ao MAPA e ao $\mathrm{CNPq}$ pelo apoio financeiro (MAPA/CNPq processo $\left.n^{\circ} 578645 / 2008-4\right)$. Ao médico veterinário Luiz Augusto Martins Gasparetto, Fiscal Federal do MAPA, pela facilitação durante a fase de colheita das amostras. A.A. Alfieri e J.A.N. Lisbôa são bolsistas produtividade em pesquisa do CNPq.

\section{REFERÊNCIAS}

ALFIERI, A.A.; PARAZZI, M.E.; TAKIUCHI, E. et al. Frequency of group A rotavirus in diarrheic calves in Brazilian cattle herds. Trop. Anim. Health Prod., v.38, p.521-526, 2006.

CAMPOS, F.S.; FRANCO, A.C.; HUBNER, S.O. et al. High prevalence of co-infections with bovine herpesvirus 1 and 5 found in cattle in southern Brazil. Vet. Microbiol., v.139, p.67-73, 2009.

CLAUS, M.O.; ALFIERI, A.F.; FOLGUERASFLATSCHART, A.V. et al. Rapid detection and differentiation of bovine herpesvirus 1 and 5 glycoprotein $\mathrm{C}$ gene in clinical specimens by multiplex-PCR. J. Virol. Methods, v.128, p.183-188, 2005.

CLAUS, M.P.; ALFIERI, A.F.; MÉDICI, K.C. et al. Bovine herpesvirus 5 detection by virus isolation in cell culture and Multiplex-PCR in central nervous system from cattle with neurological disease in brazilian herds. Braz. J. Microbiol., v.38, p.485-490, 2007.

COLODEL, E.M.; NAKAZATO, L.; WEIBLEN, R. et al. Meningoencefalite necrosante em bovinos causada por herpesvírus bovino no estado de Mato Grosso, Brasil. Cienc. Rural, v.32, p.293-298, 2002.

D'ARCE, R.C.F.; ALMEIDA, R.S.; SILVA, T.C. et al. Restriction endonuclease and monoclonal antibody analysis of brazilian isolates of bovine herpesviruses types 1 and 5. Vet. Microbiol., v.88, p.315-324, 2002.

DIAS, J.A.; ALFIERI, A.A.; FERREIRA-NETO, J.S. et al. Seroprevalence and risk factors of bovine herpesvirus 1 infection in cattle herds in the state of Paraná, Brazil. Transbound. Emerg. Dis., v.60, p.3947, 2013.

ELIAS, F.; SCHILD, A.L.; RIET-CORREA, F. Meningoencefalite e encefalomalácia por herpesvírus bovino-5: distribuição das lesões no sistema nervoso central de bovinos naturalmente infectados. Pesqui. Vet. Bras., v.24, p.123-131, 2004 
GOMES, L.I.; ROCHA, M.A.; COSTA, E.A. et al. Detecção de herpesvírus bovino 5 (BoHV-5) em bovinos do Sudeste Brasileiro. Arq. Bras. Med. Vet. Zootec., v.54, p.217-220, 2002.

HENZEL, A.; DIEL, D.G.; ARENHAR, S. et al. Aspectos virológicos e clínico-patológicos da infecção genital aguda e latente pelo herpesvírus bovino tipo 1.2 em bezerras experimentalmente infectadas. Pesqui. Vet. Bras., v.28, p.140-148, 2008.

HOLZ, C.L.; CIBULSKI, S.P.; TEIXEIRA, T.F. et al. Soroprevalência de herpesvírus bovinos tipos 1 e/ou 5 no Estado do Rio Grande do Sul. Pesqui. Vet. Bras., v.29, p.767-773, 2009.

LISBÔA, J.A.N.; ISERNHAGEN, A.J.; BORGES, A.S. et al. Hematological and cerebrospinal fluid changes in cattle naturally and experimentally infected with the bovine herpesvirus 5. Braz. Arch. Biol. Technol., v.52, p.69-76, 2009.

LUNARDI, M.; CLAUS, M.P.; LISBÔA, J.A.N. et al. Neurological and epidemiological aspects of BoHV-5 meningoencephalitis outbreak. Braz. Arch. Biol. Technol., v.52, p.77-85, 2009.

MÉDICI, K.C.; ALFIERI, A.A.; ALFIERI A.F. Prevalência de anticorpos neutralizantes contra o herpesvírus bovino tipo 1, decorrente de infecção natural, em rebanhos com distúrbios reprodutivos. Cienc. Rural, v.30, p.347-350, 2000.

MEYER, G.; LEMAIRE, M.; ROS, C. et al. Comparative pathogenesis of acute and latent infections of calves with bovine herpesvirus types 1 and 5. Arch. Virol., v.146, p.633-652, 2001.

NANDI, S.; KUMAR, M.; MANOHAR, M.; CHAUHAN R.S. Bovine herpesvirus infections in cattle. Anim. Health Res. Rev., v.10, p.85-98, 2009.

PARANÁ. Instituto Paranaense de Desenvolvimento Econômico e Social (IPARDES). Base de dado do estado: efetivo do rebanho de vacas ordenhadas por região geográfica em 2010. Disponível em: $<$ http://www.ipardes.pr.gov.br/imp/index.php $>$. Acessado em: 15 abr. 2011.

PRODUÇÃO DA PECUÁRIA MUNICIPAL 2010. Ministério do Planejamento, Orçamento e Gestão. Instituto Brasileiro de Geografia e Estatística, 2010. Disponível em: <http://www1.ibge.gov.br/home/ estatistica/economia/ppm/2010/default_zip municipios.shtm>. Acessado em: 22 abr. 2011.
QUEIROZ, G.R.; OLIVEIRA, R.A.M; LISBÔA, J.A.N. Doença do sistema nervoso dos bovinos no estado do Paraná diagnosticadas entre 2009 e 2012. CRMV PR., v.12, p.28-30, 2013.

RICHTZENHAIN, L.J.; BARBARINI, O.; UMEHARA, O. Rinotraqueíte infecciosa bovina: levantamento sorológico nos estados de Minas Gerais, Mato Grosso do Sul, São Paulo, Rio de Janeiro, Paraná e Rio Grande do Sul. Arq. Inst. Biol., v.66, p.83-88, 1999.

RISSI, D.R.; PIEREZAN, F.; OLIVEIRA-FILHO, J.C. et al. Abordagem diagnóstica das principais doenças do sistema nervoso de ruminantes e equinos no Brasil. Pesqui. Vet. Bras., v.30, p.958-967, 2010.

RISSI, D.R.; PIEREZAN, F.; SILVA, M.S. et al. Neurological disease in cattle in southern Brazil associated with bovine herpesvirus infection. J. Vet. Diag. Invest., v.20, p.346-349, 2008.

SALVADOR, S.C.; LEMOS, R.A.A.; RIETCORREA, F. et al. Meningoencefalite em bovinos causada por herpesvírus bovino-5 no Mato Grosso do Sul e São Paulo. Pesqui. Vet. Bras., v.18, p.76-83, 1998.

TAKIUCHI, E.; ALFIERI A.F.; ALFIERI A.A. Herpesvírus bovino tipo 1: tópicos sobre a infecção e métodos de diagnóstico. Semina Cienc. Agrar., v.22, p.203-209, 2001.

VOGEL, F.S.F.; CARON, L.; FLORES, E.F. et al. Distribution of bovine herpesvirus type 5 DNA in the central nervous systems of latently, experimentally infected calves. J. Clin. Microbiol., v.41, p.4512-4520, 2003.

WESGUEBER, J.; MASSITEL, J.L.; DOGNANI, R.; LISBÔA J.A.N. Prevalência da raiva em herbívoros domésticos do estado do Paraná, 2009 a 2011. In: ENCONTRO ANUAL DE INICIAÇÃO CIENTÍFICA, 21., 2012, Maringá. Anais... Maringá: Universidade Estadual de Maringá, 2012. p.992. (Resumo). 